\title{
The State, Citizenship Education, and International Events in a Global Age: The 2008 Beijing Olympic Games
}

\author{
WING-WAH LAW
}

Globalization extends intense economic, political, and cultural competitions among nations and cities into the realm of sport. It diminishes the significance of national borders and the role of the state, while challenging notions of citizenship and citizenship education. Numerous works on global sports and sporting events have shown that prestigious events, such as the Olympic Games, help promote democracy, improve human rights, facilitate development, and arouse national sentiments in host nations or cities. ${ }^{1}$ However, how a state can turn hosting an international sporting event into a socialization project that shapes students' different multiple citizenship domains (i.e., local, national, and global) warrants attention.

With reference to the 2008 Beijing Olympic Games, this article shows how the Chinese state continues to be a key actor in defining citizenship and citizenship education by promoting nationalism and nation-specific elements of citizenship education while linking its people to an increasingly interconnected world. In particular, this study examines why and how the Chinese state used Olympic education as a multileveled-multidimensional citizenship education project to equip students with a sense of being a host, both at the national and local levels ("we"), to receive guests from the rest of the world ("they"). It also examines how such education affected students' understanding of and affiliation with local, national, and global domains of citizenship as promoted by the state. Data are drawn from documents, observation, questionnaires completed by over 2,400 junior secondary students (aged 12-15), and 37 interviews with students and teachers in three schools in Beijing during March and April 2008.

The article first reviews the literature of globalization and citizenship, as well as studies on international sporting events. Second, it outlines the study's design and procedures. Next, it traces China's motivations to bid on the Olympic Games and examines Olympic-related host education. Fourth, it presents findings on how games-related host education impacted students' perceptions of multiple citizenships. Finally, it examines issues associated with hosting prestigious international events and citizenship education and dis-

\footnotetext{
${ }^{1}$ Maguire 1999; Black and Bezanson 2004; Malfas et al. 2004.
} 
cusses the dynamics and complexity of harnessing such hosting as a multileveled-multidimensional citizenship education project.

\section{State, Globalization, Gitizenship, and Citizenship Education}

Certain notions are traditionally associated with nation-specific civic elements (Heater 1999). For example, national identity is associated with a given polity's historic territory and memories, common culture(s), legal and political traditions, and common economy within recognized geopolitical borders (Smith 1991). Citizenship is membership with prescribed rights and responsibilities and can be further expressed as a sense of identity, interest, and involvement in public affairs, and acceptance of basic social values (Cogan 2000). Citizenship education is designed to prepare people to live and function effectively by equipping them with prescribed civic knowledge, skills, and attitudes (Banks 2004).

Since the late twentieth century, however, globalization has challenged these nation-specific notions. Some scholars regard globalization as a strong, pervasive, convergent force that erodes the significance of geopolitical borders, weakens states' power, creates a single globalizing consumer culture, and dissolves local cultures and life patterns. ${ }^{2}$ However, other scholars criticize this convergence thesis for overestimating the prevalence of global forces over national and local ones and defend the continuing importance of nation states. ${ }^{3}$ Between these two views, some argue that homogeneous and heterogeneous effects of globalization coexist. That is, interactions among global, national, and local forces can be intertwined and outcomes depend on their chemistry, rather than on some mechanical determination, such that one type of force must prevail over others (Featherstone and Lash 1995; Murray 2006).

In a similar vein, the state's role in responding to globalization and maintaining nation-specific characteristics in their national education systems is also debated in the education literature. For example, David Hartley (2003) notes the structural convergence in the pattern of educational governance across some societies, but Patricia Kubow and Paul Fossum (2007) argue that, according to their own specific contexts, nations address educational issues, such as the purposes of schooling, educational access and opportunity, and education accountability and authority, in different ways.

The questioning of the importance of state and national borders in a global age extends to the literature of citizenship and citizenship education (Law 2004). One school of thought moves the locus of citizenship from the national to other levels by downplaying traditional and national characteristics. For example, Gerard Delanty (2000) advocates a global cosmopolitan citizenship, whereas T. K. Oommen (1997) and Julian Nida-Ruemelin (2002)

\footnotetext{
${ }^{2}$ See, e.g., Fukuyama (1992); Ohmae (1995); Oommen (1997)

${ }^{3}$ See, e.g., Green (1999); Currie and Subotzky (2000).
} 
stress the importance of individual or group identity in understanding citizenship. Another, more inclusive, school expands people's identity in a multileveled polity from national citizenship to include personal group, local, and global dimensions. Examples of this include nested or multiple citizenship identities (Preston 1997; Heater 2004) and multilayered citizenship (Bottery 2003). Concerns about multiple citizenships are conspicuous in massive international migrations that involve changes in living or work sites. The multiple identities of migrants and local residents in host societies, as argued by Carola Suárez-Orozco (2004), are fluid and contextually driven, and can involve at least three cultures: the original culture of migrants, the culture of host people, and the global culture.

In response to globalization, inclusive frameworks for citizenship education also have been developed. For example, Patricia Kubow, David Grossman, and Akira Ninomiya (2000) propose a multileveled-multidimensional model of citizenship education with four dimensions: personal, social, spatial, and temporal. The personal dimension is the possession of such personal qualities as critical thinking, sensitivity to cultural differences, and willingness to protect environment and engage in public life; the social dimension refers to living, working, and interacting with people in various settings, including political arenas and other social areas of civil society; the spatial dimension of a multileveled polity is related to overlapping communities, ranging from local to regional, national, and multinational; and the temporal dimension is concerned with one's historical rootedness by knowing one's own and world history and having a sense of imagined connectedness to the future. Many societies have adopted such accommodative models to equip students with basic civic knowledge, skills, and attitudes for living in a multileveled polity, but they differ in emphases and contents, depending on their state's preferences and national contexts. ${ }^{4}$

China adopted a similar multileveled-multidimensional framework for its citizenship education. In the late 1970s, China began using the market to revive its socialist economy and to open up to the world, including capitalist countries. This brought changes to its socialist citizenship curriculum. As some Chinese scholars (e.g., Lee and Ho 2005) have noted, China began to broaden its socialist-collective-oriented curriculum by including the importance of individual well being and moral character. Recognizing the increasing competition between countries and domestic changes, China revised the entire school curriculum in the early 2000 s with a view to equipping students

\footnotetext{
${ }^{4}$ For example, in the United Kingdom, the compulsory citizenship curriculum for secondary students highlights the importance of developing interconnectedness between the United Kingdom and the rest of the world but, at the same time, stresses the importance of equipping students to think critically and express their opinions and helping them understand British citizens' rights and responsibilities and the features of British institutions, traditions, and civic values, such as democracy and justice (Qualifications and Curriculum Authority 2007). In a similar way, Japan's curriculum reform intended to equip students to become "cosmopolitan Japanese" and preservers of Japanese cultural traditions and values (Nakasone 1984; Lincicome 1993).
} 
with knowledge and skills to cope with these challenges (Ministry of Education 2001). As part of the reform, citizenship curriculum standards for school students were revised (Zhu and Feng 2008). In the revised junior secondary curriculum, the personal-social domain emphasizes understanding personal growth and development, developing civility, and mastering basic social manners at home and in school and society (Ministry of Education 2003). The local (collective) domain focuses on helping students understand their local community, care about local developments and social problems, and keep social order. The national domain aims to help students know and care about China's national policies and developments, love China, and understand the contribution of the Communist Party of China (CPC) to China's revival. The global dimension is directed toward developing students' global outlook, grasp of major international trends, and understanding of the importance of world peace. These domains are not separate but intertwined; for example, teaching about the world can also be associated with teaching about China's position in the world.

Extant research on globalization and education does not examine why and how China's state turned hosting the Olympic Games into a multileveledmultidimensional citizenship education project for students. To some extent, this inadequacy is supplemented by literature on international sporting events and nation building. According to David Black and Janis van der Westhuizen (2004), these events can help nation building in three major aspects: democratization and political liberalization, development, and identity building and international signaling. Hosting prominent international events requires increased interaction between international and domestic politics, which can promote democracy and human rights, either indirectly (through domestic cultivation and enhancement of civil society and social capital) or more directly (e.g., when transnational and domestic human rights organizations pressure countries to conform to international human rights legislation; Black and van der Westhuizen 2004). Many human rights groups similarly hoped that the Beijing Olympics would provide an opportunity to pressure China's ruling party to improve its human rights record (Black and Bezanson 2004).

International sporting events, such as the Olympic Games, are also seen as agents of modernization and development, particularly for the host cities (Collins 2006). Host cities must meet mandated Olympic standards, and many have used the games to develop short- and long-term development strategies, engage in urban development and regeneration, and rebrand and promote themselves (Gold and Gold 2008).

Moreover, international sporting events can promote nationalism. Such promotion incites nations to bid for international sporting events (Tomlinson and Young 2006), and hosting can reinforce people's national identity and cohesion by arousing national sentiment and building solidarity toward a common cause, for example, successful delivery of the event (Whitson 2004). 
Purpose of the Research

This study explores how China's state utilized the opportunity of hosting the 2008 Olympic Games to promote Olympic-related host education as a multileveled-multidimensional citizenship education project. It also examines the extent to which this host education project affected some Beijing junior secondary students' different domains of citizenship. Three interrelated research questions were addressed:

1. What were major motivations of China's bid to host the 2008 Olympic Games?

2. What major Olympic education initiatives did China use to promote host education for the games?

3. In what ways and to what extent did this Olympic-related host education project affect students' knowledge, skills, and/or attitudes in (a) local, (b) national, and (c) global domains of citizenship?

\section{Research Methods}

For this study I adopted a mixed research methodology by using both quantitative and qualitative approaches: document analysis, observations, questionnaires, and interviews. I collected and examined documents, including government policy documents, Olympic readers for students, and school documents and records of activities relating to Olympic education. Analyzing these documents helped me to retrace events and their developments, as well as portray the values and beliefs of the people involved (Marshall and Rossman 2006). In particular, document analysis helped to identify the historical and contemporary contexts in which the event was hosted and students lived and to reconstruct a picture of why and how China's state made use of hosting the games to promote its development agenda. I also unobtrusively observed school activities, including banners, school notices, and students' work (such as drawings and compositions), and school environments relating to Olympic education in and outside the classroom. These observations helped provide snapshots of the setting in which informants were thinking and reacting (Wiersma and Jurs 2004).

Moreover, I administered a questionnaire to identify the views of a larger sample of students while also conducting interviews to enable in-depth probing with a smaller subsample of students as well as a sample of teachers. The questionnaire had three parts. The first part had 16 questions, eliciting personal information, including gender, grade, place of birth, length of stay in Beijing, and the original domicile of respondents' parents. The second part had eight questions, which explored students' perceptions of the types and frequencies of activities offered by the school in promoting Olympic education and the school's emphases of these activities in terms of the relation- 
ship of the Olympic Games to Beijing, China, and the world. ${ }^{5}$ Because the study was only a snapshot of a particular event at single point in time, the third part of the questionnaire (31 questions) explicitly and specifically asked students about the extent to which Olympic-related host education helped them improve their knowledge, social manners and skills, attitudes, and emotional attachment in the global, national, and local (Beijing) dimensions of their citizenship. The entire questionnaire took less than 30 minutes to complete.

After analyzing preliminary findings from the questionnaire, my research team and I conducted semistructured interviews with students and teachers. They were asked how their schools organized and promoted Olympic education, what kind of Olympic-related activities they took part in, and how and why these activities had affected, for example, their understanding and sense of belonging to the games, their nation and city, and the world.

This study included students (grades 7-9, aged 12-15) from three junior secondary schools in Beijing. I used two criteria for choosing junior secondary schools: they (1) provided Olympic education and (2) had both local students and migrant students whose parents moved to Beijing from other places in China to earn their living. The first criterion was required by the major purpose of the study. The second criterion was used because migrant students accounted for 18.1 percent of the junior secondary student population in Beijing in 2007 (Beijing Municipal Education Commission 2008). Some studies (e.g., Wu 2004; Wang 2005) also show that migrant children were marginalized in the public educational system and had difficulty integrating into the mainstream school life in local public schools as well as in society and culture at large.

The major fieldwork of the study was conducted in March and April 2008. Before the 2008 Olympics, many schools in Beijing were reluctant to receive researchers, limiting selection. Such reluctance was understandable in the context of social unrest in Tibet in March 2008 and later the introduction of measures tightening social control ahead of and during the Olympic Games (Reuters 2008). With the help of several local experts in teacher training, over 20 public junior secondary schools in Beijing were contacted, but only three agreed to participate in the study. The three selected schools met the two criteria for selection. In particular, school A joined the "heart-to-heart" partnership program (officially called the One-School-One-Country Program) to participate in exchange activities with a sister school in another country. School B was recognized as an Olympic education model school. School C was not only recognized as an Olympic education model school but also joined the "heart-to-heart" program (which is described later).

A total of 2,411 questionnaires were distributed in class to all students

${ }^{5}$ In parts 2 and 3, where questions were found to have very high reliability (Cronbach's alpha $=$ 0.981), a four-point Likert scale was used: $1=$ no improvement at all or strongly disagree, $2=$ some improvement or disagree, $3=$ large improvement or agree, and $4=$ very large improvement or strongly agree. 
from grades 7 to 9 and collected by homeroom teachers at each school. The return rate was 100 percent. All returned questionnaires were usable. Of the student respondents, 49.2 percent were male, and 50.8 percent female; 29.9 percent were in grade $7,34.3$ percent in grade 8 , and 35.8 percent in grade 9; 88.3 percent were born in Beijing. The majority of the 11.7 percent who were born outside Beijing had lived in Beijing for more than 10 years. ${ }^{6}$

Individual interviews were conducted with 22 teachers, including teachers of political education and homeroom teachers who were involved in promoting and/or teaching Olympic education. School authorities arranged 15 focus group interviews with students from each grade, which included 57 (72 percent) local and 22 (28 percent) migrant students. The interviews ranged from 20 to 50 minutes, with an average interview time of 30 minutes. All interviews were conducted in Putonghua (China's national oral language) and audiotaped with permission. The data were transcribed to provide complete interview records and to facilitate data analysis.

This study has some limitations, including the small number of schools selected (as there are about 360 and 59,000 junior secondary schools in Beijing and China, respectively), the nonrepresentativeness of the schools and (possibly) the students and teachers responding to questionnaire and interview questions, and the timing of the research (i.e., pre-event only). However, there is no intent to generalize findings to other students and teachers in these schools or to other schools in Beijing or China.

\section{Motivations of China's Bid to Host the Olympic Games}

China's bid to host the Olympic Games was driven by its legacy of "national insult" by other countries in the nineteenth century and its contemporary agenda of modernization and development under the CPC's leadership. The state used hosting as an impetus for national and local developments and as a signal marking the beginning of China's rejuvenation.

First, China's bid was driven by its legacy of "national insult," which had occurred when it suffered a series of military defeats by Western powers and Japan between the 1840s and 1890s. These defeats, as Wang Gangwu (1977, 9) argued, hurt "Chinese pride" and undermined a "long-unchallenged understanding of China's place in the world" but forced China to recognize its backwardness, particularly in economic and technological developments. After assuming power in 1949, the Communist Party of China, as the ruling party, considered the modernization of socialist China as an important national development goal. China also integrated with the global economy by joining the World Trade Organization in 2002.

Hosting the Olympic Games in China had been a "dream" of many Chi-

\footnotetext{
${ }^{6}$ This figure of migrant students varied somewhat across the three schools ( 10.3 percent in school A, 12.2 percent in school $\mathrm{B}$, and 13.4 percent in school $\mathrm{C}$ ).
} 
nese people since it had first been proposed in 1908, as signaling of the revival of the Chinese nation (Beijing Organizing Committee for the Games of the XXIX Olympiad [BOCOG ] and Beijing Municipal Education Commission 2006b, 167). Since 1949, national sports teams have been mainly funded and administered by the state. Two major events revitalized the Chinese dream of hosting the Olympic Games: the Chinese women's volleyball team's winning five consecutive world titles between 1981 and 1986 and China's winning 15 gold medals in the 1984 games, breaking its humiliating "nil" record. In its second bid, China won the opportunity to host the 2008 Olympics.

Second, China's state used hosting the games as a catalyst for modernization and nation rebuilding. Despite its concessions to the International Olympic Committee (IOC), such as promises to increase media freedom and improve human rights (Liu 2001), China's state was a principal agenda setter for how it used the games. For instance, the State Council (2008) spelled out national development goals through hosting the Beijing Olympics: promoting China's economic and social development, presenting China to the international community, and enhancing ties between Chinese people and people of other countries. At the local level, under the motto of "New Beijing, Great Olympics," the Beijing Municipal Government adopted a strategy of using the games to help achieve four major local development goals: opening up Beijing to the world, improving the city's sustainability, upgrading city management and services, and enhancing the Beijing people's civility (Beijing Municipal Committee of the Communist Party of China 2005). ${ }^{7}$

Third, the Chinese state attempted to use the hosting of the games as a signal of its rise as a world player. Before the Olympic Games, winning the bid to host was seen as the "international community's recognition of China's comprehensive national strength," and hosting the games was regarded as an opportunity to promote achievements in economic reform and to open China to the world (BOCOG and Beijing Municipal Education Commission 2006a, 5). Half a year after the games, in his speech at Cambridge University, China's Premier Wen Jiabao (2009) said that what "the Beijing Olympic Games showcased is a colorful China," which is "both ancient and modern" and is "constantly developing and changing."

However, China's state was concerned that the Olympic Games might be tarnished by some Chinese people's poor civility, social manners, and habits being exhibited in and outside of sports venues before and during the games (Li et al. 2008; Peng 2008). In 2004, Beijing Mayor Wang Qishan specifically expressed that one of his greatest worries about the Olympic Games was the great variation in Beijing people's civility at such an important international event (Guo 2004). He even reminded his fellow citizens that foreigners com2008).

${ }^{7}$ For example, the construction cost for infrastructure in Beijing was about RMB300 billion (Wang 
ing to China to attend the Olympic Games would be more interested in seeing how the Chinese people had changed than the buildings. In response and as a national project of Olympic education, China's state promoted "being a good host" as a way to improve its citizens' social manners and behaviors, especially in Beijing. According to Liu Qi, President of the Beijing Organizing Committee for the Games of the XXIX Olympiad, feeling like a host could strengthen one's sense of collective mission and responsibility to contribute to the Olympic Games, and fostering civility would be part of this contribution (Li 2007).

\section{China's Olympic Education Initiatives: Host Education}

As promised in the Olympic bid, China provided education to promote Olympism, which, as Deanna Binder (2002) observed, has remained the key component of Olympic education programs in host cities. ${ }^{8}$ However, the Chinese state went beyond this and became the principal shaper of Beijing Olympic education, and it dominated the governance of the event-organizing committee. It also turned Olympic education into host education for the games, emphasizing Chinese citizens as hosts ("we") and people from other countries as guests ("they"). It broadened the scope of Olympic education from mainly Olympism to a broader, multileveled-multidimensional citizenship education, with more emphasis on national and local dimensions than on the global one.

Communist Party-Led State's Domination in Organizing the Olympic Games and Olympic Education

In China, Beijing Olympics and Olympic education were considered so important that China's vice president, not its sports minister, was their political overseer. The BOCOG was loaded with key political officials in the Communist Party and state governance. Its President, Liu Qi, was a member of the Politburo, the highest decision-making body of China, and a former mayor and party secretary of Beijing; one of its Vice Presidents, Liu Yandong, was another Politburo member and former head of the United Front Work Department; another Vice President, Chen Zhili, was State Councillor and former Minister of Education. The BOCOG also included numerous officials from various ministries of the State Council who comprised the membership of many subcommittees. As one of its Executive Vice Presidents, Liu Jingmin (2007) admitted, the BOCOG had 650 Communist Party members and 22 party

\footnotetext{
${ }^{8}$ The founder of the Olympic Movement, Pierre de Coubertin (1966) argued that Olympism is education, particularly the holistic education of body, mind, and spirit. It blends sports and sportsmanship with culture and education, emphasizes the global spread of knowledge and human development (Loland 1995; Crowther 2004; Smith 2004; Chatziefstathiou and Henry 2007), and seeks to create what the Olympic Charter describes as a "peaceful society concerned with the preservation of human dignity" (International Olympic Committee 2007, 11).
} 
groups. In short, the Communist Party-led national leadership, not local authorities, governed the BOCOG.

The Curriculum and Other Activities of Olympic-Related Host Education

Olympic-related host education extended throughout China's entire educational system. The BOCOG and the Ministry of Education (2005) issued an action plan for Beijing Olympic education, targeting 400 million children, which indicated the importance of promoting "Olympic spirit, internationalism," and sports in schools, while expressing a desire to use the Olympic Games to promote "the spirit of patriotism," to strengthen "ideological and moral education for children and young people," and to give the world a "legacy of Olympic education with Chinese characteristics." Moreover, it required schools to help students develop a strong awareness of "being a good Olympic Games host" (zuo hao ao yun hui dong dao zhu yi shi), even though most of them would not directly interact with foreign athletes, spectators, or visitors. The action plan also suggested school activities, including the use of readers to integrate Olympic education with school teaching, the heart-toheart sister school project, and a competition for model schools of Olympic education.

\section{Beijing Etiquette Readers and Olympic Readers}

The BOCOG used Beijing Olympic readers to promote its multileveledmultidimensional citizenship education. To help schools and others, the BOCOG and its approved agencies published two series of textbooks, aimed at different target groups, which reflected the major features of the Beijing Olympic education curriculum. The three schools I studied used the parts for secondary students in both series in their lessons and extracurricular activities.

The first series comprised three etiquette readers and focused on the personal-social dimension of citizenship, which intertwined with other dimensions. These etiquette readers aimed to help primary, secondary, and university students develop appropriate social manners for different occasions. The etiquette reader for secondary students introduced the cultures and lifestyles of other people, such as Americans and the Japanese (Dong 2005). It also suggested appropriate spectator behavior (e.g., switching off cell phones, knowing when to and when not to keep silent) and outlined good social manners (such as punctuality and respect for privacy and diversity). It reminded students about the importance of not disgracing China by their behaviors and social manners, including encouraging them to queue for public transport and not to litter.

The second series consisted of four 2008 Beijing Olympic readers that focus more on the global and national dimensions of citizenship education. Both dimensions were intended to reinforce students' national identity and arouse their national sentiments. For example, the reader for secondary 
students had two parts. The first four chapters introduced the history, spirit, symbols, and developments of the Olympic Games, while the following seven focused mainly on China and the 2008 Beijing Olympics (BOCOG and Beijing Municipal Education Commission 2006b). A content analysis of this reader reveals its focus on reinforcing students' Chinese national identity and pride in hosting the games. Even in the first part, significant events or moments in the Olympic Games were illustrated through photos mainly depicting China's Olympic participation: the Chinese team's procession at an Olympic opening ceremony and Chinese athletes on the podium. In a chapter introducing 19 outstanding Olympic athletes in pursuit of excellence, seven were Chinese, with five included under the theme "Their Home Country Was Proud of Them." At the end of the section, a tally table listed China's Olympic gold medalists since 1984, rather than listing outstanding medalists of different countries (98).

The second part of the reader explained the mottoes, themes, and goals of the Beijing Olympics and highlighted the infrastructure that Beijing had constructed. One chapter was overtly characterized by strong nationalism, reminding students of China's national sadness at not being awarded the 2000 Olympics and its joy in receiving the 2008 games. To explain why the world chose China to host the games, the chapter used China's achievements and features, including the dramatic increase in its national economic and athletic competitiveness over a relatively short period of about 2 decades, its mix of traditional cultures and modernization, and its record of contribution to the Olympic Games. More than three pages were devoted to comparing China's status in the international community before and after the People's Republic of China was founded in 1949 (167-70). Students were reminded of China's poor Olympic Games record, the national insult of being labeled the "sick man of East Asia" (dong ya bing fu), and how the Communist Partyled state had helped China become one of the great sporting nations.

\section{Heart-to-Heart Partnership Program}

As part of host education, in December 2006 the BOCOG followed its predecessors to promote the heart-to-heart partnership program. Beijing's program sought to enhance direct ties between its schools and those in other countries, facilitating international student exchanges and broadening international horizons (Beijing Olympic Education Standing Office 2006). Each participating school was required to make contact and communicate with the Olympic committee and a sister school in an Olympic guest country. In Beijing, 206 schools (including schools A and $\mathrm{C}$ of this study) joined this program. By April 2008, 199 (97 percent) had connected with their target countries, and 155 (75 percent) had formed partnerships with foreign sister schools in, for example, Canada, Japan, and Russia (Beijing Olympic Education Standing Office 2008). 
Before the games, Chinese schools organized cultural weeks to introduce the history and cultures of their guest countries. Students shared ideas and experiences with sister school students through the Internet and visited guest countries' consulates in Beijing. Olympic committee representatives, consular officials, and/or national athletes from guest countries also visited schools, as did some heads of state (such as Japan's prime minister and Bulgaria's president). During the games, students attended their guest country's arrival and registration at the Olympic Village and were allowed to purchase lowpriced tickets for events featuring athletes from their guest countries, whom they were encouraged to support.

\section{Olympic Education Model Schools}

Unlike the heart-to-heart partnership program, which was limited to schools in the host city and developed from the experiences of its predecessors, the model schools program sought to motivate as many schools and students across China as possible to participate in and compete for the promotion of the 2008 Beijing Olympics and to reinforce their sense of being hosts. To foster support for the games, the BOCOG in 2005 established a competition among its approximately 400,000 primary and secondary schools to become model schools, using a differential quota policy for their distribution: about 200 were to be in Beijing as the major host city, 20 each in provinces and municipalities whose cities were to host some sporting events (including Qingdao, Qinhuangdao, Shanghai, Shenyang, and Tianjin), and 10 each in the remaining provinces and municipalities (BOCOG and Ministry of Education 2005).

By May 2008, 556 model schools (including 404 secondary schools and 152 primary schools) were officially recognized across China, with 200 in Beijing, including schools B and C of this study (Chu 2008). These model schools were required to meet five criteria: (1) have good facilities and quality physical education; (2) provide an Olympic education course as a separate module with at least 2 lesson hours per month; (3) use the readers published by the BOCOG as major textbooks; (4) organize innovative Olympic education activities that were integrated into different subjects, class activities, extracurricular activities, and sports days; and (5) "disseminate" good practices to other schools (i.e., help at least one rural school and promote Olympic education in their communities by organizing events, such as seminars and talks for citizens).

Influence of Olympic Education Initiatives on Students: Findings from Student Questionnaires and Interviews

In the three schools involved in this study, Olympic-related host education was promoted mainly through regular extracurricular activities, including national flag-raising ceremonies (mean $[M]=3.47$, with 3 and 4 representing 
"frequent" and "very frequent," respectively), special school activities ( $M=$ $3.21)$, in-class activities $(M=3.14)$, and in-class lessons $(M=2.97)$. Because citizenship education is intended to equip students with necessary knowledge, skills, and attitudes to be effective citizens (Banks 2004), findings are reported on these three areas in global, national, and local domains of citizenship education. The findings indicate that, on average, students perceived China's Olympic education to have had an impact on their knowledge, skills and manners, and sentimental attachments in the three domains. The means of individual items range from about 3.2 to 3.8 , with 3 representing large improvement and 4 representing very large improvement (see table 1). ${ }^{9}$

\section{Broadening Students' Global Domain of Citizenship}

China's Olympic education helped respondent students in these three schools to affiliate more with the games and the world by enhancing their knowledge, skills, and attitudes related to the global dimension of citizenship. Students indicated that they had significantly increased their knowledge about the Olympic Games' history $(M=3.56$, with 3 and 4 representing "large improvement" and "very large improvement," respectively) and spirit $(M=3.57$; see table 1$)$. Regarding their behavior, they strongly agreed that they closely followed news about the games $(M=3.65$, with 3 and 4 representing "agree" and "strongly agree," respectively), which was often a global concern, particularly before and during the hosting.

Moreover, Olympic-related host education helped surveyed students strengthen their affiliation with the world. On average they expressed views between agreement and strong agreement that the Beijing Olympics had helped bring them closer to the world $(M=3.54)$. First, through Olympic education they learned more about the cultures of other countries $(M=$ $3.52)$ and the world $(M=3.51)$. Second, hosting the games on Chinese soil provided surveyed students with more chances to be exposed to people of other countries $(M=3.57)$ and to talk to them $(M=3.56)$. Third, respondent students were more psychologically and cognitively prepared for interacting with the world. For the Olympic Games, they indicated that on average that they had made a large to very large improvement in their hospitality to people of other cultures $(M=3.50)$ and in their awareness of the importance of living together with other people $(M=3.58)$. They also indicated that they had made a similar level of improvement in their confidence with people of other countries $(M=3.47)$ and in their proficiency in other languages $(M=3.47)$. In interviews, many students, particularly those in the two heart-to-heart schools (A and C), indicated they learned English as their major transnational language for such reasons as "being a

\footnotetext{
${ }^{9}$ A comparison of means for all question items ( $T$-test and ANOVA) showed no statistically significant differences in students' responses by gender, birthplace, household registration, and length of stay in Beijing (see some examples of this later). By school, mean differences were very small, and some were statistically significant; this will be discussed in the next section.
} 
TABLE 1

Means of Impact of Beijing Olympic Education on Students' Three Domains of Citizenship

\begin{tabular}{|c|c|c|c|c|c|c|c|c|c|}
\hline & \multicolumn{3}{|c|}{ All Three Schools } & \multicolumn{3}{|c|}{ Mean of Individual School } & \multicolumn{3}{|c|}{$\begin{array}{l}\text { Difference in Means } \\
\text { between Schools }\end{array}$} \\
\hline & No. & Mean $(M)$ & SD & School A & School B & School C & A-B & A-C & C-B \\
\hline \multicolumn{10}{|l|}{ Global domain (including Olympic Games): } \\
\hline BOE improved my understanding of the Olympic Games' history & 2,411 & 3.56 & .71 & 3.62 & 3.49 & 3.65 & $.13^{* *}$ & -.03 & $.16^{* *}$ \\
\hline BOE improved my understanding of the Olympic Games' spirit & 2,411 & 3.57 & .69 & 3.63 & 3.51 & 3.59 & $.12 * *$ & .04 & .08 \\
\hline I followed closely news about the Olympic Games & 2,409 & 3.65 & .61 & 3.65 & 3.64 & 3.67 & .01 & -.02 & .03 \\
\hline BOE increased my closeness to the world & 2,411 & 3.54 & .76 & 3.61 & 3.50 & 3.50 & $.10 *$ & $.11 *$ & .00 \\
\hline BOE improved my understanding of the world & 2,411 & 3.51 & .78 & 3.57 & 3.44 & 3.57 & $.14 * *$ & .00 & $.14^{* *}$ \\
\hline BOE improved my understanding of other countries' cultures & 2,411 & 3.52 & .74 & 3.55 & 3.46 & 3.61 & $.09 *$ & -.06 & $.15^{* *}$ \\
\hline $\begin{array}{l}\text { BOE improved my awareness of the importance of living together } \\
\text { with other people }\end{array}$ & 2,411 & 3.58 & .71 & 3.59 & 3.57 & 3.58 & .02 & .01 & .01 \\
\hline BOE improved my hospitality toward people of other cultures & 2,411 & 3.50 & .80 & 3.55 & 3.45 & 3.53 & $.10 *$ & .02 & .08 \\
\hline BOE helped improve my proficiency in foreign languages & 2,411 & 3.47 & .78 & 3.55 & 3.40 & 3.49 & $.15^{* *}$ & .05 & .09 \\
\hline $\begin{array}{l}\text { BOE improved my confidence when interacting with people of } \\
\text { other countries }\end{array}$ & 2,411 & 3.47 & .81 & 3.51 & 3.46 & 3.40 & .05 & .10 & -.05 \\
\hline $\begin{array}{l}\text { I had more exposure to people of other countries on public occa- } \\
\text { sions or when using public transportation }\end{array}$ & 2,409 & 3.57 & .64 & 3.60 & 3.54 & 3.55 & .06 & .05 & .01 \\
\hline I had more chances to talk to people of other countries & 2,409 & 3.56 & 68 & 3.62 & 3.51 & 3.58 & $.11 * *$ & .04 & .07 \\
\hline \multicolumn{10}{|l|}{ National domain: } \\
\hline BOE improved my closeness to China & 2,411 & 3.55 & .79 & 3.56 & 3.53 & 3.59 & .03 & -.03 & .06 \\
\hline BOE improved my understanding of China & 2,410 & 3.52 & .80 & 3.57 & 3.45 & 3.59 & $.12 * *$ & -.02 & $.14 * *$ \\
\hline $\begin{array}{l}\text { I was more eager to watch events featuring Chinese athletes than } \\
\text { those without Chinese athletes } \\
\text { I would watch more events featuring Chinese athletes than without }\end{array}$ & 2,409 & 3.50 & .70 & 3.55 & 3.53 & 3.34 & .03 & $.21 * *$ & $-.19 * *$ \\
\hline $\begin{array}{l}\text { Chinese athletes } \\
\text { While watcho }\end{array}$ & 2,409 & 3.46 & .75 & 3.48 & 3.51 & 3.30 & -.03 & $.18^{* *}$ & $-.21 * *$ \\
\hline Chinese athletes participated than those in which they did not & 2,409 & 3.37 & .80 & 3.35 & 3.45 & 3.19 & $-.10 *$ & $.17 * *$ & $-.27 * *$ \\
\hline I would feel proud when Chinese athletes win medals & 2,409 & 3.75 & .53 & 3.76 & 3.72 & 3.80 & .03 & -.04 & $.08^{*}$ \\
\hline I do not care whether Chinese or non-Chinese win medals & 2,408 & 3.17 & 1.00 & 3.23 & 3.22 & 2.95 & .01 & $.27^{* *}$ & $-.26^{* *}$ \\
\hline
\end{tabular}


Local (Beijing) domain:

BOE improved my closeness to Beijing

BOE improved my understanding of Beijing

BOE improved my support to local government's plan to upgrade

Beijing's infrastructure

BOE improved my support to local government's measures to make

Beijing's environment better

BOE improved my support to local government's measures to make

better Beijing's traffic and transportation conditions

BOE improved my support to local government's measures to en-

hance Beijing people's civility

BOE improved my support to local government's initiatives to en-

hance Beijing people's social manner in public occasions and

transportation

Areas that may intertwine with one or more of the domains above:

BOE improved my civility

BOE improved my behavior on public occasions and when using

public transportation

BOE improved my social skills in cooperating with other people

$\begin{array}{rrrrrrrrr}2,411 & 3.50 & .81 & 3.51 & 3.45 & 3.60 & .06 & -.09 & .15^{* *} \\ 2,411 & 3.56 & .75 & 3.62 & 3.50 & 3.60 & .12^{* *} & .01 & .10 \\ & & & & & & & & \\ 2,411 & 3.59 & .65 & 3.61 & 3.57 & 3.62 & .04 & -.01 & .06 \\ & & & & & & & & \\ 2,411 & 3.57 & .69 & 3.62 & 3.55 & 3.54 & .07 & .07 & -.01 \\ & & & & & & & & \\ 2,411 & 3.53 & .72 & 3.56 & 3.52 & 3.48 & .04 & .08 & -.04 \\ 2,411 & 3.43 & .83 & 3.43 & 3.42 & 3.43 & .00 & .00 & .01 \\ & & & & & & & & \\ 2,411 & 3.47 & .81 & 3.45 & 3.50 & 3.41 & -.06 & .04 & -.10 \\ & & & & & & & & \\ 2,411 & 3.60 & .75 & 3.69 & 3.54 & 3.58 & .15 & .11 & .04 \\ & & & & & & & & \\ 2,411 & 3.60 & .73 & 3.65 & 3.57 & 3.56 & .09 * & .09 & .00 \\ 2,411 & 3.50 & .77 & 3.54 & 3.47 & 3.50 & .07 & .04 & .03\end{array}$

Note. - Responses scale: $1=$ no improvement at all or strongly disagree; $4=$ very large improvement or strongly agree. BOE $=$ Beijing Olympic education. Items with significance at $p<.05$ are not indicated because of large sample size.

$* p<.01$
$* * p<.00$

$* * p<.001$. 
volunteer to help them find roads" and "serving people of other countries" during the games period and, in general, "increasing one's own competitiveness" in the world (and China).

\section{Reinforcing Students' National Domain of Citizenship}

Students were more concerned about the international competition between China and other countries to host the games than the internal competition between Beijing and China's other cities. Student respondents gave somewhat higher ratings to agreeing on the importance of the 2008 Olympic Games to China $(M=3.81$, with 3 and 4 representing "agree" and "strongly agree," respectively) and Beijing $(M=3.72)$ than to other countries $(M=$ 3.43). In interviews, virtually all students of the three schools expressed that they were "proud" of China hosting the games. The main reasons students offered for wanting China to win the bid included "to fulfill China's dream" of hosting the games, "to demonstrate China's rising national strength in the world," "to have an opportunity to promote China's history and culture to the world," to allow China "to broaden its international exposure to the world," to have a "sense of honor if China succeeded in the bid," and concerns that there would have been a "loss of opportunity for directly contributing to the Olympic Games" if another country had won the bid. One grade 8 student of school C (S60) noted that, had another country won the Olympics bid, it would have implied a "gap in national strength" between China and other countries, with the latter "stronger" than China. A grade 9 student of school A (S4) expressed a similar view, mentioning that his nation needs "to try hard to reduce the gap."

Moreover, students reported that Olympic education had helped them considerably to increase their understanding of China $(M=3.52$, with 3 representing "large improvement" and 4 representing "very large improvement") and had brought them closer to China $(M=3.56)$. They also, on average, expressed agreement to strong agreement that they enthusiastically looked forward to watching $(M=3.50)$ and paying more attention $(M=$ 3.37) to events featuring Chinese athletes. Regarding the medal winners' nationality, they gave higher ratings to the item on feeling proud when Chinese athletes won medals in the games $(M=3.75)$ than the item on not caring about whether the winners were Chinese or foreigner athletes $(M=$ 3.17).

According to student responses, Beijing Olympic education also helped them improve-to between a large or a very large extent-their civility $(M$ $=3.60$ ) and social behaviors on public occasions and when using transportation $(M=3.60)$, with a view to presenting the best side of China to people of other countries. In an interview, a grade 9 student of school C (S63) said he had improved his social manners because he "wanted to be a good host 
during the Olympic Games in August 2008" and did not want to disgrace the Chinese people before foreigners.

\section{Strengthening Students' Local Domain of Citizenship}

In the local domain, students indicated strong identification with their city. They indicated that Olympic education had significantly enhanced their understanding of the city $(M=3.56$, with 3 and 4 representing "large improvement" and "very large improvement," respectively), as well as their sense of closeness to it $(M=3.50) .{ }^{10}$ They indicated strongly supporting their city government's various initiatives for the Olympic Games. Surveyed students also agreed that Beijing was more qualified than other cities in China to host the games $(M=3.10$, with 3 representing "agree" and 4 representing "strongly agree"). ${ }^{11}$ Two students from schools A and B (S8 and S35) stated that if another city had won the hosting, they would have felt "a bit disappointed," while one from school B (S30) explained she wanted Beijing to win because it was her home city. When asked why she felt a strong closeness to Beijing, one school $\mathrm{C}$ student (S55), whose household registration is outside Beijing, explained: "The longer I live in Beijing, the stronger is my sense of belonging to it. . . . The Olympic Games made me feel more that I am a part of Beijing."

According to their responses, Olympic-related host education helped students improve their civility for the city as for the nation. In interviews, some students from the three subject schools (e.g., S3, S37, and S56) suggested that, as Beijing citizens and hosts of the games, they should "protect the reputation of Beijing" by demonstrating to people of other countries "good social manners" and "hospitality" and observing "social norms" as well as "regulations." A grade 7 student of school C (S68) explained that cooperation could help Beijing people be a "good host" of the games because this could "give visitors from other countries a good impression about Beijing and China." A migrant student of school B (S41) even considered civility and good social manners as basic qualities of Beijing citizens, including herself, and her "image represented Beijing's and even the nation's."

\section{Discussion: Contentious Issues of Turning Hosting International Events into a Citizenship Education Project}

Hosting international sporting events is believed to be a strategic means of state building or rebuilding (Black and van der Westhuizen 2004). This study shows that a state can turn hosting international events such as the

\footnotetext{
${ }^{10}$ Students who were not born in Beijing $(M=3.55)$ gave a slightly higher rating of agreement on their closeness to Beijing than did those who were $(M=3.49)$, though the difference is not statistically significant. Moreover, the average degree of agreement regarding closeness to the city is the same for students with household registration in Beijing $(M=3.50)$ and those registered elsewhere $(M=3.50)$.

${ }^{11}$ The mean difference of students' ratings in this item by birthplace (less than 0.01 ) or registered domicile $(0.07)$ was very small and not statistically significant.
} 
Olympic Games into host education. China faced three contentious issues with reference to such host education: promoting global or national/local identifies, making global citizenship less abstract, and estimating the appropriate number of activities.

\section{International Events as Promoters of Global or National/Local Identities?}

Sports transcend borders, and this has been a long-cherished global aspiration of the Olympic Games, as reflected by the International Olympic Committee's (2007) protestations that they are competitions between athletes, rather than countries, and efforts to promote transnational Olympism. However, this study supports David Rowe's (1999) position that global games promote nationalism. International tournaments are important symbolic representations of interstate competitions (Elias 1996), and participating in and hosting them can promote and reinforce national/local identities on the world stage.

Nevertheless, promoting the global domain of citizenship and emphasizing national and local ones, as this study demonstrates, are not necessarily mutually exclusive. China's case illustrates how a state can use hosting an international event as both an adhesive force, drawing the host country and city closer to the world, and a cohesive one, pulling people together to stage the games. The IOC President Jacques Rogge (2008) clearly had such a winwin situation in mind at the closing ceremony of the Beijing Games when he asserted that through the games "the world learned more about China, and China learned more about the world."

\section{Global Citizenship: Too Abstract and Remote to Students?}

The second contentious issue in multileveled citizenship education is how to help students understand and experience global citizenship, which has been criticized for being "too abstract to be valuable in driving . . . active citizenship for students" (Davies 2006, 5). However, China's case shows that concrete programs to provide students with direct points of interaction with people of other countries can promote the global domain of citizenship education. The "heart-to-heart" program may have had a significant impact on shaping students' affiliation to the Olympic Games and the world. The two heart-to-heart schools (A and C) had significantly higher scores, respectively, on numbers 8 and 3 of the 12 global domain items compared to school B (see cols. A-B and C-B in table 1 ). ${ }^{12}$ The items shared by schools A and $\mathrm{C}$ included understanding the Olympic Games, understanding the world, and understanding other countries' cultures. These findings suggest that hosting international events may provide students with opportunities to

${ }^{12}$ Owing to the limitations of the research design as stated earlier, it was difficult to make sure that the differences in students' responses were the direct result of Olympic education activities. 
broaden their global concerns, be exposed to cultures of different people, and interact with other people.

Are Few or Many Host Education Activities Beneficial?

The third contentious issue of host education as a multileveled-multidimensional citizenship education project is in promotion and implementation. As citizenship education involves inculcating knowledge, skills, and/or attitudes in each domain, it is difficult to balance the quantity and quality of activities within a short period. China's case shows how schools' choices can affect the types and extents, and therefore the quality, of their participation in host education activities.

Both "model schools" (B and C) had more Olympic education activities than the nonmodel school (A). However, student questionnaire responses suggested that schools $\mathrm{B}$ and $\mathrm{C}$ were not necessarily better at improving students' multiple citizenship education domains than school A. ${ }^{13}$ On the contrary, students of the nonmodel school (A) gave statistically significantly higher ratings on 11 items in the three domains of citizenship in comparison to school B (see cols. A and B in table 1) and on five items in the three domains in comparison to school $\mathrm{C}$ (see cols. A and $\mathrm{C}$ in table 1). Perhaps even more important is to note that for the seven items in the national domain, school A students gave significantly higher ratings on one and four items $(p<.001)$ in comparison to their respective counterparts of schools B and $\mathrm{C}$, as both used many materials from the Olympic readers, which were filled with Chinese nationalist messages. Comparison between the two model schools further showed that school B students gave statistically significantly higher ratings on 4 national domain items $(p<.001)$ than students of school $\mathrm{C}$, which also provided students with activities for the heart-to-heart program. In an informal conversation, one school C teacher (T21) stated that his school had held so many Olympic Games activities that time to help students consolidate their understanding was limited. In comparison, school A's activities were held on a smaller scale, which, according to a teacher in charge of some Olympic activities (T6), enabled students to better understand the purposes of and lessons to be learned from Olympic education activities.

\section{Conclusion}

This article argues that China's bid to host the Beijing Games was driven by both domestic economic and sociopolitical demands. China's state turned the Beijing Olympic Games into a state event and used its wider socialization agenda to provide Olympic education within a multileveled-multidimensional citizenship education framework. The findings do not support certain glob-

\footnotetext{
${ }^{13}$ Due to the limitations of the research design, at one point in time it was difficult to know how much change actually took place in any of the schools.
} 
alization perspectives (e.g., Fukuyama 1992; Ohmae 1995) that view the role of state as having a diminished role in defining notions of citizenship and citizenship education. This study also does not support arguments that see a simplistic replacement of national/local citizenship with a global, group, or individual one, or vice versa (e.g., Oommen 1997; Nida-Ruemelin 2002). On the contrary, with reference to the Beijing Olympic Games, this study demonstrates that the state was a key player in global and domestic events. It further reveals the dynamic interplay among actors at different levels.

First, the state is a key actor in nation (re)building, interpreting, and responding selectively to growing global influences. As a major controller and allocator of public resources, the state can influence the event's organizing committee and set national economic and sociopolitical development goals. The state can also be a principal designer, promoter, and provider of event-specific, multileveled-multidimensional citizenship education activities. On the one hand, it can select what global elements will be included and emphasized and reinterpret and re-present them to its people. On the other hand, the state can promote nationalism by introducing a temporal dimension of citizenship education (by relating the event to the nation's past, present, and future) and by prescribing the spatial and personal-social dimensions with contents filled with nation-specific sociopolitical purposes and elements, (e.g., enhancing people's civility and linking the event, the ruling party, and the people). The host city can assist the national state by interpreting and implementing national initiatives, as well as introducing local initiatives designed to meet local needs.

Second, schools are important domestic actors, mediating interactions among students, the world, and their nation and city. Schools-and the educators that work in them-are also immediate agents of socialization and immediate providers of event-related host education prescribed by the state and/or local government. They can have different selections and intensities of host education activities and, therefore, as shown in the three Beijing schools, can have different influences on students' perceptions and experiences of different domains of citizenship. However, provision of education for students with too many activities in all major citizenship domains within a short period could interfere with students' consolidating their learning about multiple citizenship education.

Third, students are major consumers of event-specific, multileveled-multidimensional citizenship education. They are likely to be influenced by providers of such education. In this study, most of the findings suggest that surveyed students adopted the version of Olympic-related host citizenship education as prescribed by the Chinese government or had already developed such views prior to the Olympic education programs. Despite the internal distinction between local and migrant students, education in hosting international events working as a common external stimulus appeared to bring 
surveyed students closer to their city and nation. Students were not necessarily passive consumers, however. In the study, despite considerable similarities in responses, there were students with differing views. The differences among students of the three schools were reflected by the standard deviations on the questionnaire items, ranging from .53 to .83 (see the column on standard deviation in table 1). Similar extents of differences among students within schools were found. In interviews, two students, as mentioned earlier, provided possible explanations for China if it failed to win the bid to host the 2008 games. Additionally, although some students of schools B and C (e.g., S39 and S65) supported the city government's plan to improve people's civility, they expressed doubts about how long Beijing people's improved behavior on public occasions or in public places would last after the games.

In sum, this case study of how Olympic education was organized and its impact on the views of students in three schools in Beijing shows that host education and its influences on students depend on intertwined interactions between international and domestic actors, as well as the needs, conditions, and contexts of host countries or cities for nation building or rebuilding. It should be noted that the Beijing Olympic Games in China was a special international event, and so was the China's multileveled citizenship education project through Olympic education. More research in international and comparative education in the future is required to investigate how international events with different scales and levels of significance, hosted in different countries with different histories and national strengths, could affect chemistries of interactions and various domains of citizenship education.

\section{References}

Banks, James A. 2004. "Democratic Citizenship Education in Multicultural Societies." In Diversity and Citizenship Education: Global Perspectives, ed. James A. Banks. San Francisco: Jossey-Bass.

Beijing Municipal Committee of the Communist Party of China. 2005. Guanyu Zhiding Beijing Shi Guomin Jingii He Shehui Fazhan Di Shiyige Wunian Guihua De Jianyi [Suggestions for the 11th five-year plan for the economic and social developments of Beijing]. Beijing: Communist Party of China's Beijing Municipal Committee.

Beijing Municipal Education Commission. 2008. 2007 Nian Jiaoyu Shiye Zonghe Qingkuang [A brief statistical report on educational achievements and developments in Beijing, 2007]. Beijing: Beijing Municipal Education Commission.

Beijing Organizing Committee for the Games of the XXIX Olympiad (BOCOG) and Beijing Municipal Education Commission. 2006a. Beijing Aoyunhui Gongzuo Renyuan Duben [The service guide of 2008 Beijing Olympics for staff]. Beijing: Beijing Sports University Press.

Beijing Organizing Committee for the Games of the XXIX Olympiad (BOCOG) and Beijing Municipal Education Commission. 2006b. Beijing Aoyunhui Zhong- 
xuesheng Duben [2008 Beijing Olympic reader for secondary school students]. Beijing: Beijing Publishing House.

Beijing Organizing Committee for the Games of the XXIX Olympiad (BOCOG) and Ministry of Education. 2005. Beijing 2008 Zhongxiao Xuesheng Aolinpike Jiaoyu Jihua [Action plan for 2008 Beijing Olympic education for primary and secondary school students]. Beijing: Ministry of Education.

Beijing Olympic Education Standing Office. 2006. Tongxinjie Changye Xini Jingyan $J i$ [Heart-to-heart: The experience collection of Nagano and Sydney]. Beijing: Beijing Olympic Education Standing Office.

Beijing Olympic Education Standing Office. 2008. "Beijing Shi Aolinpike Jiaoyu Gongzuo Jianbao" [Beijing Olympic education working report]. Report, April 4.

Binder, Deanna. 2002. "The Legacy of the Olympic Games for Education, 1984-2000." Conference report to the International Olympic Committee Symposium on the Legacy of the Olympic Games, Lausanne.

$\rightarrow$ Black, David R., and Shona Bezanson. 2004. "The Olympic Games, Human Rights and Democratisation: Lessons from Seoul and Implications for Beijing." Third World Quarterly 25 (7): 1245-61.

Black, David R., and Janis van der Westhuizen. 2004. "The Allure of Global Games for 'Semi-Peripheral' Polities and Spaces: A Research Agenda." Third World Quarterly 25 (7): 1195-1214.

$\rightarrow$ Bottery, Mike. 2003. "The End of Citizenship? The Nation State, Threats to Its Legitimacy, and Citizenship Education in the Twenty-first Century." Cambridge Journal of Education 33 (1): 101-22.

$\rightarrow$ Chatziefstathiou, Dikaia, and Ian Henry. 2007. "Hellenism and Olympism: Pierre de Coubertin and the Greek Challenge to the Early Olympic Movement." Sport in History 27 (1): 24-43.

Chu, Xiao Qing. 2008. "Youxiu Aolinpike Shifanxiao Rongyu Liangxiang” [Result of outstanding Olympic model schools]. Beijing Chenbao [Beijing Morning Post], April 29, 8.

Cogan, John J. 2000. "Citizenship Education for the Twenty-first Century: Setting the Context." In Citizenship for the 21st Century: An International Perspective on Education, ed. John J. Cogan and Ray Derricott. London: Kogan-Page.

$\rightarrow$ Collins, Sandra. 2006. "Epilogue (of the Special Issue on Olympism: The Global Vision; From Nationalism to Internationalism)." International Journal of the History of Sport 23 (7): 1253-55.

Coubertin, Pierre de. 1966. The Olympic Idea: Discourses and Essays. Lausanne: Editions Internationales Olympic.

$\rightarrow$ Crowther, Nigel. 2004. "The State of the Modern Olympics: Citius, Altius, Fortius?" European Review 12 (2): 445-60.

Currie, Jan, and George Subotzky. 2000. "Alternative Responses to Globalization from European and South African Universities." In Globalization and Education: Integration and Contestation across Cultures, ed. Nelly P. Stromquist and Karen Monkman. Lanham, MD: Rowman \& Littlefield.

$\rightarrow$ Davies, Lynn. 2006. "Global Citizenship: Abstraction or Framework for Action?" Educational Review 58 (1): 5-25.

Delanty, Gerard. 2000. Citizenship in a Global Age: Society, Culture, Politics. Buckingham: Open University Press. 
Dong, Feng Chu, ed. 2005. Zhongxuesheng Liyi [Secondary student etiquette reader]. Beijing: Hongqi Publishing House.

Elias, Norbert. 1996. The Germans: Power Struggles and the Development of Habitus in the Nineteenth and Twentieth Centuries. Cambridge: Polity.

Featherstone, Mike, and Scott Lash. 1995. "Globalization, Modernity and the Spatialization of Social Theory: An Introduction." In Global Modernities, ed. Mike Featherstone, Scott Lash, and Roland Robertson. London: SAGE.

Fukuyama, Francis. 1992. The End of History and the Last Man. New York: Free Press. $\rightarrow$ Gold, John R., and Margaret M. Gold. 2008. "Olympic Cities: Regeneration, City Rebranding and Changing Urban Agendas.” Geography Compass 2 (1): 300-318.

$\rightarrow$ Green, Andy. 1999. "Education and Globalization in Europe and East Asia: Convergent and Divergent Trends." Journal of Education Policy 14 (1): 55-71.

Guo, Kun. 2004. "Wang Qishan: 08 Aoyun 8 Yue 8 Ri Wan 8 Shi Kaimu Zui Danxin Shimin Suzhi” [Wang Qishan expressed worry about citizen's quality during the opening ceremony of the Beijing Olympic Games on August 8, 2008]. Jinghua Shibao [Beijing Times], November 5.

$\rightarrow$ Hartley, David. 2003. "Education as a Global Positioning Device: Some Theoretical Considerations." Comparative Education 39 (4):439-50.

Heater, Derek Benjamin. 1999. What Is Citizenship? Cambridge: Polity.

Heater, Derek Benjamin. 2004. A History of Education for Citizenship. London: RoutledgeFalmer.

International Olympic Committee. 2007. Olympic Charter. Lausanne: International Olympic Committee.

Kubow, Patricia K., and Paul R. Fossum. 2007. Comparative Education: Exploring Issues in International Context. 2nd ed. Upper Saddle River, NJ: Pearson/Merrill/Prentice-Hall.

Kubow, Patricia, David Grossman, and Akira Ninomiya. 2000. "Multidimensional Citizenship: Educational Policy for the 21st Century." In Citizenship for the 21st Century: An International Perspective on Education, ed. John J. Cogan and Ray Derricott. London: Kogan-Page.

$\rightarrow$ Law, Wing-Wah. 2004. "Globalization and Citizenship Education in Hong Kong and Taiwan." Comparative Education Review 48 (3): 253-73.

$\rightarrow$ Lee, Wing On, and Chi Hang Ho. 2005. "Ideopolitical Shifts and Changes in Moral Education Policy in China." Journal of Moral Education 34 (4): 413-31.

Li, Chuan Zhu 2007. "Liu Qi: Shenru Kaizhan Ying Aoyun Jiang Wenming Shuxinfeng Huodong" [An interview with Liu Qi: Activities of "welcome the Olympic Games, emphasize civility, and build new tradition”]. Qiushi Journal, June 20, 7.

Li, He, Yan Jin Liu, and Liao Cao. 2008. "Liyi Zhongguo Wuhuanqi Xia De Chongjian Meng Xiang" [China with etiquette: To rebuild the dream under the Olympic flag]. Renmin Ribao [People's Daily], June 14, 7.

$\rightarrow$ Lincicome, Mark. 1993. "Nationalism, Internationalization, and the Dilemma of Educational Reform in Japan.” Comparative Education Review 37 (2): 123-51.

Liu, Jingmin. 2007. "Shenru Xuexi Guanche Hu Jintao Zongshuji Jianghua Jingshen Quanmian Tuijin Aoyunhui Chouban Gongzuo" [To study and implement the spirit of the spirit of General Secretary $\mathrm{Hu}$ Jintao and to advance the fullscale preparation for the Olympic Games]. Qianxian [Frontline Monthly] 1: $12-14$. 
Liu, Qi. 2001. Zai Beijing Daibiaotuan Mosike Chenshu Baogao" [A statement in the presentation of the Beijing delegation for the bid for 2008 Olympic Games in Mosco]. Statement to the International Olympic Committee, Moscow.

Loland, S. 1995. "Coubertin's Ideology of Olympism from the Perspective of the History of Ideas." Olympika: The International Journal of Olympic Studies 4:49-78.

Maguire, Joseph. 1999. Global Sport, Identities, Societies and Civilizations. Cambridge: Polity.

$\rightarrow$ Malfas, Maximos, Eleni Theodoraki, and Barrie Houlihan. 2004. "Impacts of the Olympic Games as Mega-Events.” Municipal Engineer 157 (3): 209-10.

Marshall, Catherine, and Gretchen B. Rossman. 2006. Designing Qualitative Research. 4th ed. Thousand Oaks, CA: Sage.

Ministry of Education. 2001. Jichu Jiaoyu Kecheng Gaige Gangyao Shixing [Guidelines on the curriculum reform of basic education]. Beijing: Beijing Normal University Press.

Ministry of Education. 2003. Zhixiang Pinde Kecheng Biaozhun: Shiyangao [Curriculum standard for ideology and moral character: Pilot version]. Beijing: Ministry of Education.

Murray, Warwick E. 2006. Geographies of Globalization. London: Routledge.

Nakasone, Yasuhiro. 1984. "Speech Made by the Prime Minister Mr. Yasuhiro Nakasone at the First Meeting of the National Council on Educational Reform (September 5, 1984)." In Reports on Education Reform, ed. National Council on Educational Reform. Tokyo: Government of Japan.

Nida-Ruemelin, Julian. 2002. "Redefining Citizenship.” Taipei Times, January 30, 9.

Ohmae, Kenichi. 1995. The End of the Nation State: The Rise of Regional Economics. New York: Free Press.

Oommen, T. K. 1997. "Introduction: Conceptualizing the Linkage between Citizenship and National Identity." In Citizenship and National Identity: From Colonialism to Globalism, ed. T. K. Oommen. New Delhi: Sage.

Peng, Lin. 2008. "Tisheng Wenming Chongjian Liyi" [To raise civility and reconstruct etiquette]. Renmin Ribao [People's Daily], June 14, 7.

Preston, P. W. 1997. Political/Cultural Identity: Citizens and Nations in a Global Era. London: Sage.

Qualifications and Curriculum Authority. 2007. Citizenship: Programme of Study for Key Stage 3 and Attainment Target. London: Department for Education and Employment, and Qualifications and Curriculum Authority.

Reuters. 2008. "Local Officials Urged to Grant Media Freedom.” South China Morning Post, July 24, A4.

Rogge, Jacques. 2008. "IOC President's Speech at the Closing Ceremony of the Games of the XXIX Olympiad (August 24).” http://www.olympic.org/uk/news/ olympic_news/full_story_uk.asp?id $=2776$.

Rowe, David. 1999. Sport, Culture and the Media. Buckingham: Open University Press.

Smith, Anthony D. 1991. National Identity. London: Penguin.

Smith, Michael Llewellyn. 2004. Olympics in Athens 1896: The Invention of the Modern Olympic Games. London: Profile Books.

State Council. 2008. Zhengfu Gongzuo Baogao [Report on the work of the government]. Beijing: People's Press.

Suárez-Orozco, Carola. 2004. "Formulating Identity in a Globalized World." In 
Globalization: Culture and Education in the New Millennium, ed. Marcelo M. SuárezOrozco and Desirée Qin-Hilliard. Berkeley: University of California Press.

Tomlinson, Alan, and Christopher Young, eds. 2006. National Identity and Global Sports Events: Culture, Politics, and Spectacle in the Olympics and the Football World Cup. New York: State University of New York Press.

Wang, Gangwu. 1977. China and the World since 1949: The Impact of Independence, Modernity and Revolution. London: Macmillan.

Wang, Lu. 2005. "The Urban Chinese Educational System and the Marginality of Migrant Children.” In Chinese Citizenship: Views from the Margins, ed. Vanessa Fong and Rachel Murphy. London: Routledge.

Wang, Wei. 2008. “Aoyun Bu Hui Chengwei Zhongguo Jingji Fazhan De Fenshuiling” [The Beijing Olympic Games would not become the watershed in China's economic development]. Renmin Ribao [People's Daily], August 19, 2.

Wen, Jiabao. 2009. "Yong Fazhan Yanguang Kan Zhongguo Zai Jianqiao Daxue De Yanjiang" [See China in the light of her development]. Speech at the University of Cambridge, February 2. Renmin Ribao [People's Daily], February 4, 3.

$\rightarrow$ Whitson, David. 2004. "Bringing the World to Canada: 'The Periphery of the Centre." Third World Quarterly 25 (7): 1215-32.

Wiersma, William, and Stephen G. Jurs. 2004. Research Methods in Education: An Introduction. 8th ed. Needham Heights, MA: Allyn \& Bacon.

Wu, Xin Hui. 2004. "Guanzhu Liudong Renkou Zinu De Shehui Rongru Zhuangkuang-Shehui Paichi De Shijiao” [Social integration of migrant workers' children into host society: A perspective from social discrimination]. Shehui [Society] 24 (9):10-12.

$\rightarrow$ Zhu, Xiao Man, and Xiu Jun Feng. 2008. "On the Development of Citizenship Education Outlook in China." Frontiers of Education in China 3 (1): 1-21. 